\title{
LEARNING GENERATORS: RESEARCH ON CHILDHOOD LEARNING STYLES TO ACCELERATE SECOND LANGUAGE EDUCATION
}

Text books are tools that generate learning, and if we improved them taking into account the different learning styles, we would be creating a real Learning Generator for all the students, without any exception at all. It seems utopia, but it would be an attainable utopia if we prepared text books that could make them learn at their maximum capacities. Could we imagine a learning system where all students learned at their best? What degree of knowledge could those students end up reaching?

Keywords: Childhood teaching, Learning styles, Second Language education, Text books,

\section{Introduction}

We are all different and individuals differ in how they learn. The different Learning styles are the differences in individuals' pattern of acquiring and processing information in learning situations. The idea of individualized learning styles originated in the 1970s, and has deeply influenced the educational methodologies. It is recommend that teachers assess the learning styles of their students and adapt their classroom methods to best fit each student's learning style, since there is evidence that students express preferences for how they prefer to receive information. These styles are assumed to be acquired preferences that are adaptable, either at will or through changed circumstances, rather than being fixed personality characteristics. In doing so, teachers should take into consideration two categorizations, one dealing the way students get information and the other on how students process this information.

\section{Literature review}

As regards the input of information in a class context, one of the most common and widely used categorizations of the various types of learning styles is Neil D. Fleming's VARK model (sometimes VAK) which expanded upon earlier Neurolinguistic programming (VARK) models: Visual learners, Auditory learners, Reading-writing preference learners and Kinesthetic learners or tactile learners. Fleming claimed that visual learners have a preference for seeing (think in pictures; visual aids that represent ideas using methods other than words, such as graphs, charts, diagrams, symbols, etc.). Auditory learners best learn through listening (lectures, discussions, tapes, 
etc.). 111 Tactile/kinesthetic learners prefer to learn via experience-moving, touching, and doing (active exploration of the world; science projects; experiments, etc.). As far as processing information is concerned, we should point out Kolb's model and the adaptation made to Kolb's experiential model by Honey \& Mumford. The stages in the cycle were named to accord with managerial experiences of decision making/problem solving, which are: Activist, Reflector, Theorist and Pragmatist. Activists like doing and experiencing. Games, practical activities, anything that is energetic and involving. Reflectors wish to have time to think, observe, take it all in, watching others, solitude and time. Theorists want to know where something fits into overall ideas and concepts, analysis and logic, being stretched, abstract concepts, structure, clarity. Pragmatists prefer practical problem solving, relevance to the real world and applying learning. The use in instruction of these different learning styles allows teachers to prepare classes that address each of these areas. Students can also use the model to identify their preferred learning style and maximize their educational experience by focusing on what benefits them the most.

\section{Research methodology}

But what if teachers chose a textbook which actually considers all this diversity? Do textbooks already consider all these different learning styles? I decided to do some research in order to find out and so as to reduce the research, I analyzed English textbooks as a Second Language. The publishing houses that were included in this research were the prestigious Pearson/Longman, Oxford, Cambridge, Heinemann/Macmillan and Richmond, and as far as Learning Styles is concerned, we should congratulate the publishing houses. After analyzing different publishing houses belonging to the same level, one of the main common attributes that have been found is the great numerical equality of exercises that could help the different systems of neurolinguistic representations. The general neurolingistic representation in the publishing houses would be; $35 \%$ of Visual, $33 \%$ of Auditory and 32\% of Kinesthetic exercises. The Oxford publishing house turns out to be the one that could help the Visual students more (50\%). Cambridge is second (41.5 $\%)$, Pearson is third (38.5\%), whereas Heinemann (24.1\%) and Richmond (20.8 $\%)$ include a smaller representation of exercises that could help this group of students. The Visual style is the one that has the greatest representation in three out of five publishing houses, although not by much from the second most frequent used style, the auditory style. The one with the greatest percentage is Heinemann (44.1\%), followed by Richmond (40.8\%) and Cambridge (30.5\%). Those that have a smaller percentage are Oxford (26\%) and Pearson (24.2\%). The Kinesthetic style is the least used in two out of five publishing houses although not by a remarkable big percentage from the 112 other representational systems, and varies between the greatest representation of Richmond (38.4\%) and the representations of Pearson (37.3\%), Heinemann (31.8\%), Cambridge (28\%) 
and Oxford (24\%). This analysis shows that the books of the most sold and used publishing houses in English teaching are close to be Learning Generators. The percentage of visual children is usually very superior to the auditory and kinesthetic children, for that reason many activities are prepared for these children. On the contrary, as far as the Learning Styles are concerned, we should criticize the work of the publishing houses. One of the main common characteristics after analyzing the same publishing houses is the great representation of exercises that a particular Learning Style has over other Styles. The average representation in percentages of the Learning Styles would be; $18.4 \%$ of Activists, $49.4 \%$ of Reflectors, $17.8 \%$ of Theorists and $14 \%$ of Pragmatists. The Reflector Style, with a representation of $49.4 \%$, is the Style which all publishing houses help most. This data is common in all the analyzed publishing houses. The Activist Style is second if we consider the average, with an $18.4 \%$ representation, but it has only been the second most recurring Style in three of the five publishing houses. The third most common Style is the Theorist Style, with a $17.8 \%$, which is also the second most seen Style in three of the five analyzed publishing houses. The Pragmatist Style, with an average of $14 \%$, has been the least recurrent Style in three of the five publishing houses, and it is, the Style with the smallest representation in general. The Richmond publishing house turns out to be the one that could help the Activist students most (30\%). The Pearson publishing house is second (23\%) and Cambridge and Heinemann are third $(17 \%)$, whereas Oxford has the smallest representation of exercises that could help this group of students. The Reflector Style is the one that has the greatest percentage in all the publishing houses, and with a clear advantage in percentage from the second dominant Style. The publishing houses with the highest percentage $(56 \%)$ are Oxford, and on the other hand, Heinemann is the one that has the lowest percentage (43 $\%)$. As it can be verified, the highest score and the lowest do not distant to a great extent. Heinemann is also the publishing house with the greatest percentage in exercises with Theorist Style (29\%). Oxford is second (22\%). Cambridge (17\%) and Pearson (14\%) are in the following positions and Richmond has the lowest percentage (7\%). The Pragmatist Style is the least recurrent style and varies between Pearson and Heinemann (11\%) and Oxford, Cambridge and Richmond $(16 \%)$. The excessive representation of exercises that could help the Learning Style with less students together with the small representation of exercises that could help the students with other styles clearly show that the text books follow a mistaken tendency. The higher representation of exercises that could help the Reflectors Style verifies that all the publishing houses, without any exception, follow the natural method. 113 The publishing houses do not consider the different Learning Styles of the students, and they are focused on a method that will soon be obsolete because the academic results do not show good results. 


\section{Results}

After analyzing the main deficiencies, some activities were created so as to deal with the failures of the analyzed text books (schemes, additional material for the teacher...), and verified if the modifications previously mentioned were effective as far as the attainment of the targets offered by each book, using a control group to which these modifications were not applied $|6|$. The results were highly encouraging since the students with Learning Styles of smaller representation in text books obtained better results than those that did not do the activities, since they belonged to the control group. This proved that the complementary activities that had been prepared to replace the deficiencies of books, adding exercises and activities that could help students from no-Reflectors Learning Style were positive. To my concern, the academic results of those students with Activist Style are usually much worse than the students with Theorist and Reflector Style, probably due to the insistence of the publishing houses to help them in text books. We can conclude with clear evidence that the publishing houses do not consider the different Learning Styles at the time of programming their books. On the one hand, they do not seem to consider the percentage of representation of the pupils belonging to each Learning Style. But on the other hand, they seem to consider the spread tendency in the different methods of education of the foreign languages, since they are centered in the natural method, leaving aside, for example, grammar explanations that would could help students with Theorist Style. Paradoxically, they do not turn out to be very communicative since they do not include a great variety of communicative exercises, which could help the students from Activist and Pragmatist Style. This must be because the text books are designed considering educative contexts where classes have a large number of students, which makes the accomplishment of these activities difficult. But this investigation has ended up finding the main failure of the tendency in education in second languages; the communicative method fails because it has an excessive use of exercises of a single Style, which is the one used by the smallest number of students (Reflector Style). After analyzing the learning styles in the text books used to learn English as a second language, changes should be made to improve the quality of books as they only help a small percentage of students. The excessive use of exercises that help the Learning Style with less students and the small representation of exercises which help students with other styles shows that text books follow a mistaken tendency. The higher representation of exercises that could help the Reflector Style shows that all the publishing houses, without exception, follows the natural method. The 114 natural method fails because it has an excess of a single Learning Style, which is the one with the smallest representation among the students (Reflector Style). 


\section{Conclusions}

Text books act like a tool that generates learning, and if we bettered it considering the different Learning Styles, we would be creating a Learning Generator: an optimal tool of learning. Now it is time for the publishing houses to pay greater attention to the theories on Learning Styles than to the educative tendencies, as the communicative and natural methodologies in foreign languages could not help all the students. The diversity of learning styles and the student's different level in a school subject should not be a problem if we used a never-failing learning generator: the digital book |2|. The evolution of the textbook towards the digital book is now in the Spanish classrooms |11|. The new technologies are here to stay due to its countless advantages. The only possible problem is the lack of teachers ' technological command $|3|$. It seems that the role of the teacher is changing dramatically, since we used to pass knowledge and now we are mere guides $|8|$. It also seems that the textbook is also evolving and that the paper format will end up being replaced by a digital format book. Everything seems to point that both evolutions will be overlapped and the education classroom will evolve into online education |12|. As the American writer Elbert Hubbard said "The object of teaching a child is to enable him to get along without his teacher". Can we imagine a learning system where all the students learned at their best? What degree of knowledge could those students end up reaching? The traditional role of the teacher has been the omniscient presence in every classroom. They were the only ones who possessed all the knowledge which was passed on to their students. On the other hand, students were placed in rows directed towards the teacher listening to facts that the students wrote down in their notebooks. The only other source of knowledge on any particular subject was the textbook, which are assigned in a course to each student at the beginning of the school year. The most influential tool in the classrooms of today is the Internet so a teacher's role in the classroom must change. In today' fast moving world, teachers must become more of a guide. The truth is that the tech-students of today do not want to be lectured to about facts they can instantly find with the click of a button on their smart phones. Making students memorize facts is no longer sensible. This can be done by making classrooms much more student-centered than ever before. For teachers, the hardest part is letting go of control in their classrooms. Many educators are experts in what they teach, so it can be hard for them to not demonstrate their breadth of knowledge in their subjects on a daily basis. Students need to be more in control of their own learning. Consequently, educators must move aside and give up some power. This is the only way we can begin to make true educational progress, and the Internet must be our guiding force. 


\section{References}

1. C. Alonso, D. Gallego, y P. Honey. Recursos e instrumentosPsicopedagógicos. Los estilos de aprendizaje. Procedimientos de diagnóstico y Mejora. España: Universidad de Deusto, EdicionesMensajero., 1997, ch 1

2. A. Bates. Technology, e-Learning and Distance Education London: Routledge, 2005, ch 3

3. L. Cuban. "Oversold and underused: Computers in the classroom.". Harvard University Press, 2001, pp 11-23

4. A. R. Damasio, y H. Damasio. Cerebro y Lenguaje. FundamentosBiológicos II. Madrid: UNED, 1997,ch 4

5. R. Dunn,.y K. Dunn. La Enseñanza y el Estilo Individual de Aprendizaje. Madrid: Anaya, 1984, pp 34-41
6. H. Gardner. Multiple intelligences: the theory in practice. New York: Basic Books, 1993, ch 1-3

7. D. Kolb. Experiental learning: Experience as the source of Learning and Development. New Jersey: Prentice Hall, 1984, pp 41-45

8. N. Selwyn. Education and Technology: Key Issues and Debates. London: Continuum International Publishing Group.2011, pp 4-62

9. B. F. Skinner. Verbal behavior. Massachusetts: Copley, 1992, ch 3-4

10. R. Varela. Estrategias de enseñanzaaprendizaje de idiomasextranjeros. Madrid: UNED, 1998, ch 1-6

11. C. Vera. Las TIC aplicadas a la enseñanza de laslenguasextranjeras. Barcelona: Graó, 2002, ch 3-5 [12] J. M. Vez. El aula de lenguasextranjeras: umbral para unasociedad de laCultura. Barcelona: Graó, 2002, ch 4 


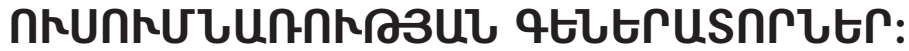

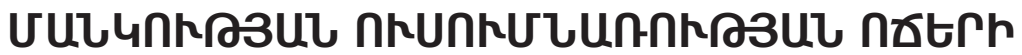

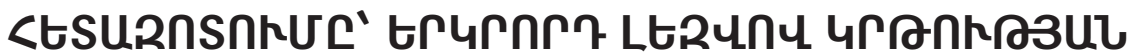 uruqusuUน しTUSU4กч}

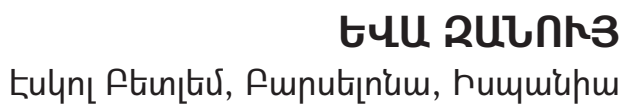

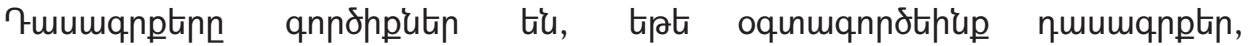

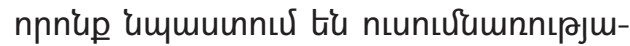

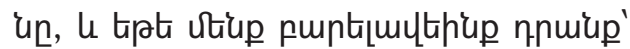

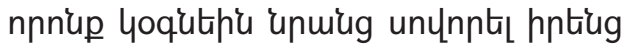

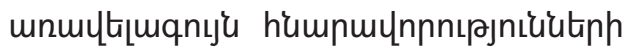
umhưuiunus: 4mpñ tüp muinltinug-

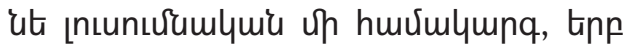

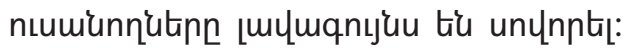

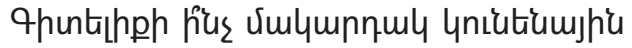

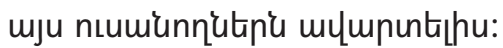

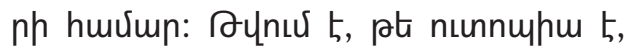

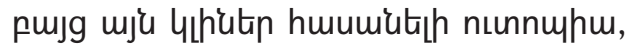

\section{ОБУЧАЮЩИЕ ГЕНЕРАТОРЫ: ИЗУЧЕНИЕ СТИЛЕЙ ОБУЧЕНИЯ ДЕТЕЙ С ЦЕЛЬЮ УСКОРЕНИЯ ОБУЧЕНИЯ НА ВТОРОМ ЯЗЫКЕ}

ЭВА ЗАНУЙ

Эскол Бетлем, Барселона, Испания

Учебники - это инструменты, способствующие обучению. Улучшая их, принимая во внимание разные стили обучения, мы создадим подлинный обучающий генератор для всех студентов без каких-либо исключений. Это похоже на утопию, однако это будет достижимой утопией, если использовать учебники, которые помогут обучаться с реализацией максимального потенциала. Можем ли мы представить себе систему обучения, когда учащиеся учатся на пределе возможного? Какой уровень знаний у них будет по окончании учебы? 